\title{
Pemberdayaan Masyarakat melalui Wirausaha Kerupuk Bonggol Pisang di Kabupaten Sukoharjo
}

\section{(Community Empowerment on Entrepreneurship by Crakers Banana Rhizome in Sukoharjo District)}

\author{
Sholichah Rohmani*, Adi Yugatama \\ Program Studi Farmasi, Fakultas Matematika dan Ilmu Pengetahuan Alam, Universitas Sebelas Maret Surakarta, \\ Jl. Ir. Sutami No. 36 A Surakarta, Jawa Tengah 57126. \\ *Penulis Korespondensi: licha.apt@gmail.com \\ Diterima Oktober 2018/Disetujui Februari 2019
}

\begin{abstract}
ABSTRAK
Salah satu bentuk usaha yang memungkinkan dilakukan oleh ibu rumah tangga adalah dengan berwirausaha membuat kerupuk. Produk olahan makanan berbahan pohon pisang dipilih sebagai usaha untuk berwirausaha karena memiliki prospek yang baik, karena selain buahnya ada bagian lain yang juga bisa dimanfaatkan seperti bonggol pisang. Mengingat manfaat dan kandungan gizi yang bagus maka diversifikasi bonggol pisang diperlukan agar produk lebih bisa diterima oleh pasar. Tujuan kegiatan ini adalah menginspirasi mitra pengabdian masyarakat tentang sebuah ide dan semangat berwirausaha dengan sumber bahan baku yang mudah didapatkan dan ada disekitar mereka sehingga dapat menambah penghasilan rumah tangga. Program ini dilakukan melalui dua tahap, yaitu pengolahan bonggol pisang menjadi kerupuk siap saji menyehatkan dan transfer teknologi pengemasan. Melalui kegiatan pengabdian kepada masyarakat ini maka dilakukan pelatihan dan pengembangan teknologi pengolahan bonggol pisang menjadi produk komoditas ekonomi berupa kerupuk, yang dapat memberikan alternatif usaha perekonomian baru di masyarakat. Dampak positif dari kegiatan ini adalah meningkatnya keterampilan dan pengetahuan mitra terkait pembuatan olahan produksi dari pohon pisang, termasuk juga mengenai teknik pengemasan terlihat dari peningkatan skills dalam mengemas produk. Terjadi peningkatan kemampuan mitra dalam berwirausaha dalam memproduksi dan menjual produk.
\end{abstract}

Kata kunci: bonggol pisang, kerupuk, Sukoharjo, wirausaha

\begin{abstract}
One effort that can be done by housewives is entrepreneurship to make crackers. Food products from banana trees were chosen because they have good prospects, besides the fruit there are other parts that can be used, namely banana humps. Because of the benefits and high nutritional content, it is necessary to diversify from banana humps to be sold. The purpose of this activity is to inspire partners about the idea and spirit of entrepreneurship using sources of raw materials that are easy to obtain, so they can increase income. The program is carried out through two stages, namely processing banana humps into healthy crackers and transferring packaging technology. This activity was carried out in the training and development of technology for processing banana humps into cracker products, which could be an alternative economic new business in the community. The positive impact of this activity is the increasing skills and knowledge of partners about making food from banana trees, as well as improving the skills of packaging techniques. There is an increase in the ability of entrepreneurial partners in producing and selling products.
\end{abstract}

Keywords: banana rhizome, crackers, entrepreneur, Sukoharjo

\section{PENDAHULUAN}

Selama ini masyarakat Indonesia masih belum mengoptimalkan potensi yang terdapat pada tanaman pisang karena penggunaannya yang hanya sebatas buah, pelepah, dan jantung saja. Bonggol pisang merupakan salah satu bagian yang paling jarang dimanfaatkan untuk dikonsumsi. Seringkali masyarakat meng- gunakannya sebagai pakan ternak atau dibuang begitu saja. Padahal bonggol pisang memiliki kandungan gizi dan serat yang cukup tinggi. Salah satu pemanfaatan bonggol pisang untuk konsumsi masyarakat adalah dengan mengolahnya menjadi kerupuk. Kerupuk merupakan makanan yang banyak disukai anak hingga orang dewasa. Selain itu, proses pembuatan kerupuk cukup mudah dan tidak rumit. Kerupuk yang dijual 
dipasaran tidak sedikit yang banyak mengandung bahan-bahan kimia tambahan, yang sebaiknya bahan tersebut dikurangi bahkan dihindari asupannya ke dalam tubuh kita. Pada zaman modern ini masyarakat ingin segala sesuatunya yang cepat, oleh karenanya banyak makanan-makanan yang dibuat secara instan untuk mengikuti keinginan masyarakat, namun segala sesuatu yang instan belum tentu baik bagi kesehatan kita. Makanan yang sering kita jumpai di era modern seperti ini salah satunya adalah kerupuk. Dilihat dari keseharian masyarakat terutama anak-anak dan remaja bahkan anak kuliah banyak yang suka ngemil. Banyak cemilan yang dijual di pasaran tetapi tidak mengandung vitamin dan nilai gizi yang tinggi dan banyak yang mengandung zat kimia yang berbahaya. Ini bisa dapat mengganggu kesehatan pada umumnya. Contohnya dapat mengakibatkan gangguan pencernaan, seperti mual, pusing, diare, dan sembelit, dalam jangka panjang bisa menyebabkan kolesterol tinggi dan penyempitan pembuluh darah.

Kebutuhan akan bahan makanan seiring waktu terus mengalami peningkatan. Hal ini dikarenakan pertambahan penduduk yang semakin banyak, sementara itu tidak dapat diimbangi dengan peningkatan sumber pangan. Berangkat dari hal tersebut maka perlu adanya inovasi dengan memanfaatkan bonggol pisang sebagai alternatif bahan pangan. Umumnya bagian yang dimanfaatkan dari tanaman pisang adalah buahnya, sementara bagian lainnya masih belum dimaksimalkan pemanfaatannya. Salah satunya adalah bonggol pisang. Kandungan karbohidrat tergolong tinggi, bahkan lebih tinggi dari jagung. Sehingga cocok digunakan sebagai bahan pangan alternatif pengganti jagung, bahkan nasi sekalipun. Minoritas masyarakat di Pulau Jawa biasa mengolah bonggol pisang dengan merebusnya, tentunya hal ini hanya akan memenuhi kebutuhan perut semata dan tidak bernilai jual, sehingga, perlu dikembangkan potensi dari bonggol pisang agar memiliki nilai jual yang lumayan, dengan mengembangkan dan mengolahnya sedemikian rupa.

Negara Indonesia merupakan salah satu negara yang dikenal sebagai produsen pisang dunia. Indonesia telah memproduksi sebanyak $6,20 \%$ dari total produksi dunia, $50 \%$ produksi pisang Asia berasal dari Indonesia (Supriyadi \& Satuhu 2008). Tanaman pisang merupakan suatu tumbuhan yang dari akar hingga daunnya dapat digunakan dan dimanfaatkan oleh manusia.
Pisang diketahui mengandung gizi tinggi dan sebagai sumber vitamin, mineral, dan juga karbohidrat. Kandungan nutrisi lainnya seperti serat dan vitamin dalam buah pisang seperti vitamin A, B, dan C, dapat membantu memperlancar sistem metabolisme tubuh, meningkatkan daya tahan tubuh dari radikal bebas, serta menjaga kondisi tetap kenyang dalam waktu lama (Rismunandar 1981).

Semua bagian tanaman pisang mulai dari akar sampai daun memiliki banyak manfaat, terutama yang banyak dikonsumsi masyarakat adalah buahnya. Sedangkan bagian tanaman pisang yang lain, yaitu jantung, batang, kulit buah, dan bonggol jarang dimanfaatkan dan dibuang begitu saja menjadi limbah pisang. Batang pisang dapat digunakan sebagai bahan dasar kertas daur ulang, bahan anyaman kerajinan, dan pakan ternak. Jantung pisang dapat digunakan sebagai bahan makanan seperti dendeng jantung pisang. Kulit pisang dapat dimanfaatkan sebagai produk olahan makanan, seperti nata dan roti. Bagian bonggol pisang juga bermanfaat sebagai bahan baku obat, yaitu dapat mengobati penyakit disentri, pendarahan usus, obat kumur, serta untuk memperbaiki pertumbuhan dan menghitamkan rambut (Rosdiana 2009). Bonggol pisang ternyata mengandung gizi yang cukup tinggi dengan komposisi yang lengkap. Bonggol pisang mengandung karbohidrat sebesar 66\%, protein, air, dan mineral-mineral penting. Bonggol pisang mempunyai kandungan pati sebesar 45,4\%, dan kadar protein sebesar 4,35\% (Munadjim 1983).

Kelurahan Kartasura, Kabupaten Sukoharjo merupakan salah satu wilayah di Jawa Tengah yang memiliki potensi yang sangat besar terhadap tanaman pisang. Hampir di setiap pekarangan rumah dan pojok-pojok sawah atau kebun ditanami oleh tanaman pisang. Pemanfaatan bonggol pisang oleh masyarakat desa ini pun masih belum optimal. Melihat potensi yang cukup besar yang dimiliki oleh desa tersebut, maka perlu dilakukan suatu program untuk meningkatkan kesadaran masyarakat akan potensi bonggol pisang dan mensosialisasikan pemanfaatan bonggol pisang sebagai bahan pangan alternatif dalam bentuk kerupuk atau kerupuk yang meyehatkan karena berasal dari bahan alam.

Produk berupa kerupuk sehat dipilih sebagai usaha untuk berwirausaha karena memiliki prospek yang baik. Selain itu kerupuk bonggol pisang bisa dijadikan peluang usaha yang 
menguntungkan karena bisa membantu peningkatan gizi, mengingat manfaat dan kandungan yang ada dalam bonggol pisang memiliki banyak kegunaan untuk dijadikan olahan masakan dengan berbagai cara, rasa, serta cara penyajian maupun makanan yang beranekaragam. Tidak boleh dilupakan juga yang harus diperhatikan adalah faktor kualitas, karena preferensi konsumen terhadap atribut produk terletak pada komponen kualitas (Herlambang et al. 2018). Kesadaran akan pentingnya kewirausahaan harus ditingkatkan dan didukung mengingat hal ini akan sangat membantu perekonomian keluarga (Rohmani et al. 2018), sehingga diharapkan mampu meningkatkan kesejahteraan penghasilan keluarga serta juga mampu berinovasi dalam memperingan pengeluaran keluarga tanpa mengurangi kebutuhan gizi keluarga karena selain nikmat juga menyehatkan.

Warga di Kelurahan Kartasura, Kabupaten Sukoharjo yang memiliki kebun yang ditanami pohon pisang adalah Ibu Harni dan Ibu Marsih. Sampai saat ini umumnya pemanfaatan pisang hanya dikonsumsi dalam bentuk segar ataupun direbus hal ini dikarenakan kurangnya pengetahuan dan keterampilan tentang pengolahan makanan kecil berbahan dasar pisang. Salah satu upaya untuk memberikan nilai tambah dari komoditas pisang adalah dengan mengolah pisang menjadi olahan makanan yang lebih bervariatif baik yang tidak hanya dari buahnya saja. Untuk mencapai tujuan tersebut tim melakukan pembinaan terhadap mitra melalui pendampingan dalam proses produksi. Selain itu juga diberikan investasi berupa hibah alat produksi. Meningkatnya kreativitas makanan berbahan dasar pisang diharapkan dapat membuka peluang usaha baru bagi masyarakat. Tujuan kegiatan ini adalah untuk menginspirasi mitra pengabdian masyarakat tentang ide dan semangat berwirausaha dengan sumber bahan baku yang mudah didapatkan dan ada disekitar mereka sehingga dapat menambah penghasilan rumah tangga.

\section{METODE PELAKSANAAN KEGIATAN}

\section{Waktu dan Tempat}

Kegiatan dilaksanakan selama 2 bulan pada bulan Juli-Agustus 2018. Lokasi kegiatan pengabdian di Desa Singopuran, Kecamatan Kartasura, Kabupaten Sukoharjo.

\section{Metode Pelaksanaan}

Metode yang digunakan dalam kegiatan pengabdian masyarakat ini adalah metode ceramah, praktik, dan diskusi. Metode ceramah digunakan untuk menjelaskan materi tentang pengolahan kerupuk bonggol pisang. Metode praktik digunakan untuk praktik membuat olahan produk berbasis bonggol pisang, mulai dari perajangan bonggol pisang sampai dengan pengolahan dan pengemasan. Aplikasi penggunaan mesin dan teknik pengemasan untuk meningkatkan mutu dan harga jual dengan packing yang berkualitas. Metode diskusi dilakukan setelah kegiatan pengabdian selesai untuk mengetahui respons peserta. Evaluasi peningkatan pengetahuan dan keterampilan dari mitra dilakukan melalui pre-test dan post-test. Monitoring dan evaluasi dilakukan pada saat program berlangsung.

\section{HASIL DAN PEMBAHASAN}

\section{Kegiatan Sosialisasi}

Sosialisasi kegiatan dilakukan bertempat di kediaman salah satu mitra pengabdian masyarakat di Desa Singopuran yang dihadiri sebanyak 11 orang. Kabupaten Sukoharjo adalah suatu wilayah potensial penghasil pisang karena daerahnya tropis basah lembap dan panas sehingga tanaman pisang tumbuh subur di wilayah tersebut. Umumnya setelah dipanen pisang dijual segar begitu saja di pasar-pasar setelah melalui pemeraman, namun tidak semua pisang hasil panen bisa diperam sehingga pisang tersebut masih mentah. Demikian pula pisang yang sudah masak dari pemeraman tidak semuanya laku terjual pada saat itu juga. Sifat pisang yang mudah busuk akan memengaruhi kualitas dan nilai jualnya. Sampai saat ini umumnya pemanfaatan pisang hanya dikonsumsi dalam bentuk segar ataupun direbus, hal ini dikarenakan kurangnya pengetahuan dan keterampilan tentang pengolahan makanan kecil berbahan dasar pisang. Salah satu upaya untuk memberikan nilai tambah adalah mengolah bonggol pisang menjadi olahan makanan yang lebih bervariatif berupa kerupuk. Meningkatnya kreativitas makanan berbahan dasar pisang diharapkan dapat membuka peluang usaha baru, sehingga diperlukan terobosan baru untuk membuat produk berbahan bonggol pisang yang sehat yang diharapkan mempunyai prospek yang bagus dan cemerlang, dan sangat diperlukan 
transfer teknologi untuk meningkatkan kualitas, nilai jual produk, serta strategi pemasarannya.

\section{Kegiatan Pemberdayaan Masyarakat}

Pemberdayaan masyarakat dilakukan melalui kegiatan pelatihan dan pendampingan dalam pembuatan produk olahan bonggol pisang dalam bentuk kerupuk, beserta cara pengemasan produknya. Adanya transfer teknologi diharapkan mampu meningkatkan kapasitas produksi dan nilai ekonomi produk. Pada kegiatan ini dilakukan pembinaan terhadap mitra melalui pendampingan dalam proses produksi kerupuk bonggol pisang. Mitra memiliki upaya pengembangan makanan sehat sebagai upaya pencegahan penyakit serta peningkatan komoditas ekonomi masyarakat, dan mengingat bahaya mengkonsumsi kerupuk yang banyak mengandung micin tidak baik bagi kesehatan maka kegiatan pengabdian masyarakat ini akan dilakukan secara terpadu untuk memberikan solusi.

- Transfer teknologi dalam pembuatan kerupuk bonggol pisang dalam kemasan

Kegiatan ini berupa ceramah dan diskusi tentang produk olahan bonggol pisang dalam bentuk jajanan sehat berupa kerupuk yang dapat diproduksi dalam skala rumah tangga. Kegiatan ini adalah transfer teknologi pembuatan kerupuk bonggol pisang inovatif dalam kemasan. Disebut kerupuk bonggol pisang inovatif karena bahan yang digunakan berbahan dasar formulasi produk kerupuk dari bonggol pisang segar yang selama ini tidak dimanfaatkan tapi ternyata bermanfaat bagi kesehatan.

\section{- Proses produksi dan packaging kerupuk bonggol pisang dalam kemasan}

Pelatihan diikuti praktik pembuatan kerupuk bonggol pisang dalam kemasan oleh kelompok mitra. Praktik secara mandiri oleh kelompok mitra didampingi oleh tim pelaksana dan dilakukan untuk meningkatkan keterampilan praktis para anggota mitra. Pada kegiatan praktik produksi kerupuk, dimulai dengan proses pembuatan kerupuk dengan bahan dasar bonggol pisang, yang dibuat dengan cara dicampur dengan tepung kanji serta ditambahkan bumbu lainnya sebagai pelengkap dan perasa. Proses pembuatan kerupuk bonggol pisang terlihat pada Gambar 1.

Bonggol pisang atau batang pisang bagian bawah merupakan bagian yang paling jarang dimanfaatkan, apalagi untuk dikonsumsi. Selama ini masyarakat menggunakannya sebagai bahan makanan ternak, untuk pembuatan pupuk K, dan sabun dengan cara dibakar sampai menjadi abu. Air bonggol pisang dapat dimanfaatkan untuk menyembuhkan berbagai macam penyakit,

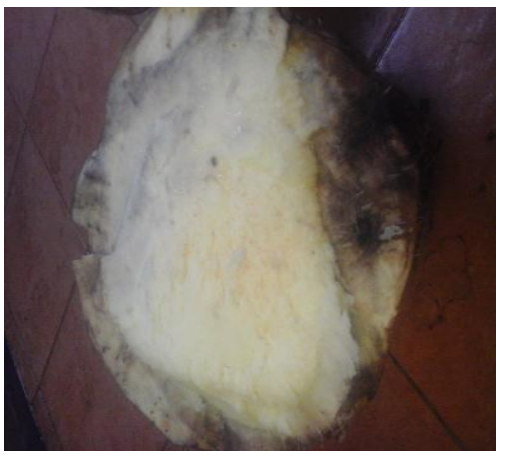

a

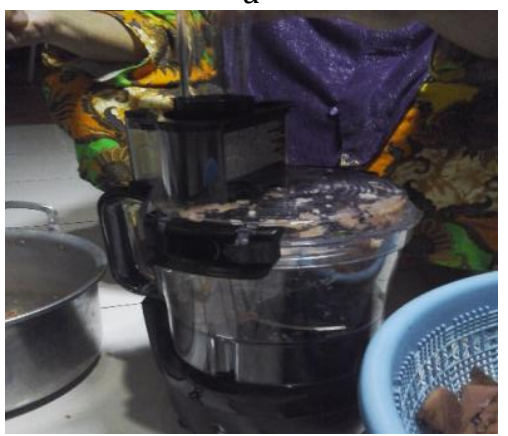

d

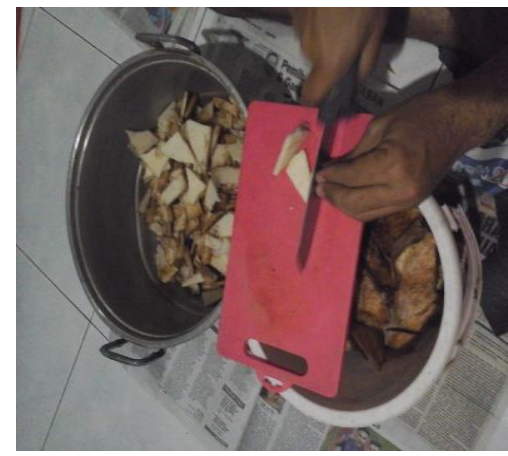

b

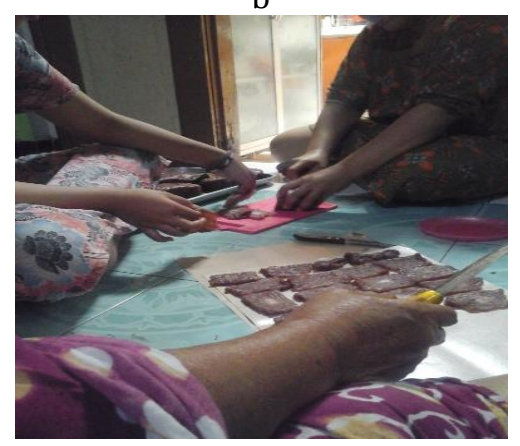

e

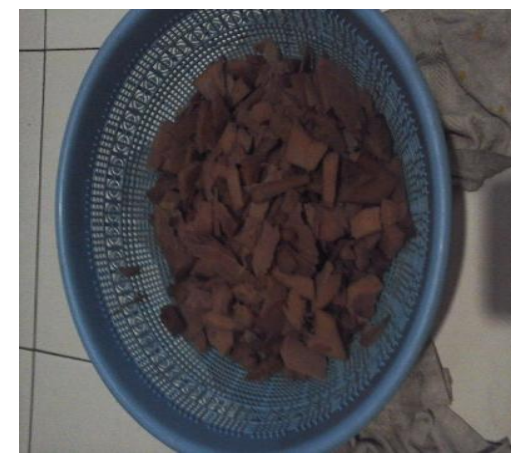

C

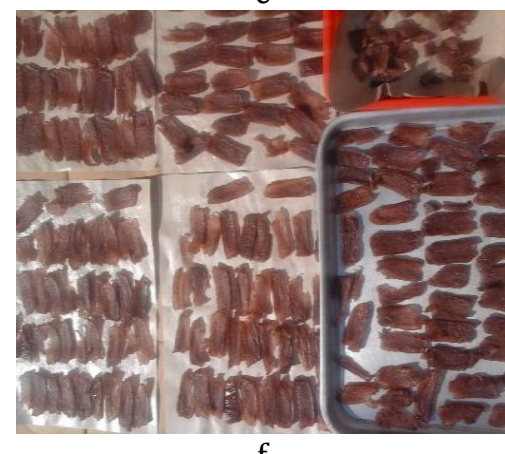

f

Gambar 1 Proses pembuatan kerupuk bonggol pisang a) Bonggol pisang; b) Proses pengirisan bonggol pisang; c) Bonggol pisang setelah direbus; d) Proses penggilingan/penghalusan bonggol pisang; e) Adonan dipipihkan; dan f) Dijemur hingga kering. 
seperti disentri, pendarahan usus, amandel, serta dapat memperbaiki pertumbuhan dan menghitamkan rambut. Bonggol pisang masih banyak yang dibuang begitu saja dan menjadi limbah, padahal bonggol pisang dapat dimafaatkan 100\% untuk konsumsi, yang berarti seluruh bagiannya bisa dimakan. Bonggol pisang belum dimanfaatkan oleh masyarakat desa secara optimal sebagai komoditas yang memiliki nilai lebih, padahal bonggol pisang mengandung karbohidrat yang cukup tinggi. Hasil penelitian menunjukkan komposisi bonggol pisang meliputi pati sebesar $76 \%$, dan air sebesar $20 \%$. Dalam $100 \mathrm{~g}$ bahan bonggol pisang kering mengandung karbohidrat sebesar 11,6 g (Yuanita 2008). Jadi selain bonggol pisang memiliki nilai gizi yang tinggi juga akan melengkapi penganekaragaman bahan pangan serta mengembangkan penggunaan bahan makanan tradisional (Asriyana et al. 2018).

Bonggol pisang juga memiliki kandungan serat dan kalsium yang cukup tinggi, sehingga dapat menjadi sumber serat dan kalsium alternatif. Kandungan karbohidrat yang tinggi menjadi keunggulan bagi bonggol pisang karena dapat menjadi bahan subtitusi bagi beras, apalagi ditunjang dengan kalori yang besar sehingga dapat menjadi sumber energi bagi para konsumen. Bonggol pisang selain kaya serat, juga dapat memperlancar pencernaan dan mengurangi sembelit, di balik cap-nya sebagai 'limbah' batang pisang bagian bawah ini ternyata mengandung gizi yang cukup tinggi dengan komposisi yang lengkap. Dalam $100 \mathrm{~g}$ bonggol pisang basah terkandung kalori sebesar 43,0; protein sebesar 0,36 g; karbohidrat sebesar $11,60 \mathrm{~g}$; air sebesar $86,0 \mathrm{~g}$; beberapa mineral seperti Ca, P, Fe, vitamin B1, dan C, serta bebas kandungan lemak (Rukmana 2005). Secara lengkap kandungan gizi dalam bonggol pisang basah dan kering dapat dilihat pada Tabel 1.

Setelah proses produksi kegiatan dilanjutkan dengan proses pengemasan. Pengemasan adalah kegiatan merancang dan memproduksi wadah atau bungkus sebagai sebuah produk (Kotler \& Keller 2009). Pengemasan adalah aktivitas merancang dan memproduksi kemasan atau pembungkus untuk produk. Biasanya fungsi utama dari kemasan adalah untuk menjaga produk, namun sekarang kemasan menjadi faktor yang cukup penting sebagai alat pemasaran (Rangkuty 2010). Kerusakan bahan pangan dapat disebabkan oleh dua hal, yaitu kerusakan oleh sifat alamiah dari produk yang berlangsung secara spontan dan kerusakan karena pengaruh lingkungan. Oleh karena itu, diperlukan pengemas untuk membatasi bahan pangan dengan lingkungan untuk mencegah atau menunda proses kerusakan sehingga produk mempunyai daya tahan lebih lama untuk dikonsumsi (Nur 2009). Kerupuk bonggol pisang yang sudah dikemas terlihat pada Gambar 2.

Sebagai kegiatan akhir dilakukan evaluasi untuk kelompok sasaran yang terdiri atas a) Evaluasi peningkatan pengetahuan kelompok sasaran melalui pre-test dan post-test; dapat dilihat dari yang awalnya belum paham akan manfaat limbah bonggol pisang, setelah mendapat pelatihan menjadi paham dan mampu mengolah menjadi kerupuk; b) Evaluasi peningkatan keterampilan kelompok sasaran; dan c) Evaluasi dampak kegiatan. Kegiatan pengabdian masyarakat yang telah dilakukan ini tentunya membawa dampak yang lebih baik bagi mitra, antara lain 1) meningkatnya keterampilan dan pengetahuan mitra terkait pembuatan olahan produksi dari pohon pisang, termasuk juga mengenai teknik pengemasan terlihat dari

Tabel 1 Kandungan gizi dalam bonggol pisang

\begin{tabular}{lrr}
\hline \multicolumn{1}{c}{ Kandungan gizi } & $\begin{array}{r}\text { Bonggol } \\
\text { basah }\end{array}$ & $\begin{array}{r}\text { Bonggol } \\
\text { kering }\end{array}$ \\
\hline Kalori (kal) & 43,00 & 245,00 \\
Protein (g) & 0,36 & 3,40 \\
Lemak (g) & 0,00 & 0,00 \\
Karbohidrat (g) & 11,60 & 66,20 \\
Kalsium (mg) & 15,00 & 60,00 \\
Fosfor (mg) & 60,00 & 150,00 \\
Zat besi (mg) & 0,50 & 2,00 \\
Vitamin A (SI) & 0,00 & 0,00 \\
Vitamin B1 (mg) & 0,01 & 0,04 \\
Vitamin C (mg) & 12,00 & 4,00 \\
Air (g) & 86,00 & 20,00 \\
Bagian yang dapat & 100,00 & 100,00 \\
dimakan (\%) & & \\
\hline
\end{tabular}

Sumber: Rukmana (2005).

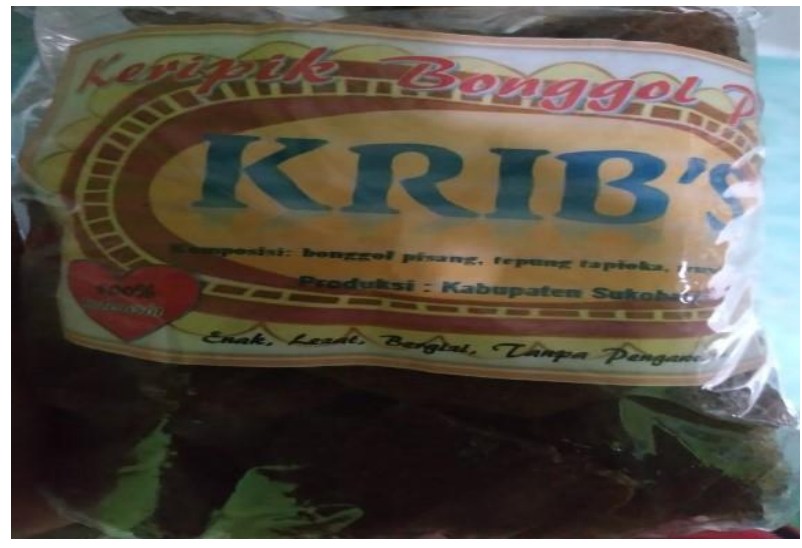

Gambar 2 Kerupuk bonggol pisang yang sudah dikemas. 
peningkatan skills dalam mengemas produk, di mana untuk tiap bonggol pisang yang diolah bisa menghasilkan 25-35 bungkus kerupuk mentah dan 2) Peningkatan kemampuan mitra dalam berwirausaha dalam memproduksi dan menjual produk. Tim pengabdian juga menghibahkan mesin penunjang produksi, yaitu food processor, oven pengering, hand sealer, dan timbangan.

\section{SIMPULAN}

Kegiatan pengabdian untuk pemberdayaan masyarakat dalam membuat produk olahan kerupuk dari bonggol pisang membawa dampak positif. Selain untuk meningkatkan nilai ekonomi dari bonggol pisang juga memberi manfaat bagi mitra, yaitu meningkatnya keterampilan dan pengetahuan mitra terkait pembuatan olahan produksi dari pohon pisang, termasuk juga mengenai teknik pengemasan. Hasil dari kegiatan ini terlihat ada peningkatan kemampuan mitra dalam berwirausaha dalam memproduksi dan menjual produk. Kedepannya produk bisa di daftarkan ke dinkes setempat untuk bisa mendapatkan sertifikat PIRT.

\section{UCAPAN TERIMAKASIH}

Ucapan terima kasih kepada Universitas Sebelas Maret Surakarta, yang telah mendanai kegiatan ini sehingga kegiatan ini terlaksana dengan baik dan lancar.

\section{DAFTAR PUSTAKA}

Asriyana, Irawati N, Haslianti. 2018. Pemberdayaan Masyarakat Berbasis Potensi Sumber Daya Perairan di Desa Tanjung Tiram, Kabupaten Konawe Selatan, Sulawesi Tenggara. Agrokreatif Jurnal Ilmiah Pengabdian kepada Masyarakat. 4(1): 12-21. https://doi.org/10.29244/agrokreatif.4.1.1221

Herlambang A, Asmawati E, Haryono Y. 2018. Implementasi Cara Produksi Pangan yang
Baik Untuk Industri Rumah Tangga Kerupuk di Sidoarjo. Agrokreatif Jurnal Ilmiah Pengabdian kepada Masyarakat. 4(1): 31-37. https://doi.org/10.29244/agrokreatif.4.1.3137

Kotler P, Keller KN. 2009. Manajemen Pemasaran. Jilid I, Edisi 13. Jakarta (ID): Erlangga.

Munadjim. 1983. Teknologi Pengelolaan Pisang. Jakarta (ID): PT. Gramedia.

Nur M. 2009. Pengaruh Cara Pengemasan, Jenis Bahan Pengemas, dan Lama Penyimpanan Terhadap Sifat Kimia, Mikrobiologi, dan Organoleptik Sate Bandeng. Jurnal Teknologi dan Industri Hasil Pertanian. 14 (1): 1-11.

Rangkuty F. 2010. Strategi Promosi yang Kreatif dan Analisis Kasus Integrated Marketing Communication. Jakarta (ID): Gramedia Pustaka Utama.

Rismunandar. 1981. Penyakit Tanaman Pangan dan Pembasmiannya. Bandung (ID): Sinar Baru.

Rohmani S, Yugatama A, Prihapsara F. 2018. Inovasi Minuman Sehat Berbahan Kedelai dalam Upaya Pemberdayaan Masyarakat melalui Wirausaha di Kabupaten Sukoharjo. Agro Kreatif Jurnal Ilmiah Pengabdian kepada Masyarakat. 4(2): 68-74. https://doi.org/ 10.29244/agrokreatif.4.1.68-74

Rosdiana R. 2009. Pemanfaatan Limbah dari Tanaman Pisang. Jakarta (ID): Bharatara Karya Aksara.

Rukmana R. 2005. Aneka Olahan Limbah:Tanaman Pisang, Jambu Mete, Rosella. Yogyakarta (ID): Kanisius.

Supriyadi A, Satuhu S. 2008. Pisang Budidaya Pengolahan dan Prospek Pasar. Jakarta (ID): Swadaya.

Yuanita N, Raqhmawati Y. 2008. Pabrik Sorbitol dari Bonggol Pisang (Musa Paradisiaca) dengan Proses Hidrogenasi Katalitik. [Tesis]. Surabaya (ID) Institut Teknologi Sepuluh Nopember. 